\title{
Sentiment Analysis of Smartphone Accounting Application Users
}

\author{
Kholifah Fil Ardhia,* \\ ${ }^{\text {a} V o c a t i o n a l ~ P r o g r a m ~ o f ~ A c c o u n t i n g, ~ P o l i t e k n i k ~ H a r a p a n ~ B e r s a m a, ~ k h o l i f a h f i l a r d h i @ ~ g m a i l . c o m, ~ I n d o n e s i a ~}$
}

\begin{abstract}
The focus of this research is to summarize the reviews conducted by accounting application users to explore what aspects they like about the accounting application. This research uses review sentences with a total of 4923 review sentences on Google and Apple platforms. The review mining method used in this study implements the Feature-Based Summarization (FBS). The conclusion of this study is that there are six product features that are preferred by accounting application users. The product features are reports, transactions, bookkeeping, profit, category, and customers. This research has explored product features in accounting applications, but not all product features are discussed by users. Therefore, the discussion on review sentences focuses on the six product features. This study is able to provide practical recommendations to Small-Medium Enterprises (SMEs) actors in making smartphone-based application decisions they will use. This study recommends SMEs to use accounting applications with the above product features. This is because the strong discussion of opinions on product features explains the preference for product features for actors in helping them prepare financial reports. As qualitative research, this study does not have the ability to generalize the results of the study to a population.
\end{abstract}

Keywords: Accounting Application, SMEs, Accounting Technology, Data Mining

${ }^{*}$ Corresponding author. E-mail: kholifahfilardhi@gmail.com 


\section{Introduction}

The digital accounting ${ }^{l}$ era has opened up opportunities for accounting information technology to be accepted by the SMEs sector (Grande, Estébanez, \& Colomina, 2011). This is supported by the penetration of smartphone users in Indonesia in 2018 reaching $56.2 \%$ of the total population (Jamilah, 2020). There are many free and feature-rich applications available for smartphone (Pramono, Mardini, Suangga, \& Ilhamsyah, 2020) to preserve SMEs in preparing financial reports. The main phenomenon of digital accounting, namely reviews by users of accounting applications with large number of reviews. This is evidenced by the large number of smartphone-based accounting application users. Data obtained from the official Play Store website shows that the BukuKas and Daily Financial Notes application has been downloaded more than one million downloads (Google, 2021). The total investment of Rp 709 billion has succeeded in embracing 6.3 million shop owners and SMEs players, even with 3 million active users being able to produce a total annual SMEs transaction worth almost US \$ 25.9 billion (Zhafira, 2021). Study by Mahrus et al. (2020) shows the opposite situation that the majority of the population has difficulty using smartphone-based accounting applications. This is due to the low accounting knowledge of SMEs actors. This phenomenon opens opportunities for accounting information technology in studying the acceptability of technology systems with abundant unstructured data.

The review information above can help users make decisions in determining which applications are suitable for their use. Review sentences contain information on how users accept a product or service (Guo, Zhang, Wang, \& Chen, 2019; M. Hu \& Bing, 2004; Y.-H. Hu, Chen, \& Chou, 2016) especially accounting applications. Users discuss various product features in related review sentences whether they feel that the product features help them or not. Meanwhile, one application is able to get a total of 62,402 reviews (Google, 2021). The phenomenon of reviewing sentences (unstructured data) needs to be processed to extract user acceptability factors. Research conducted by (M. Hu \& Bing, 2004) offers a method for processing linguistic data to summarize the sentiment of opinion.

\footnotetext{
${ }^{1}$ Digital Accounting refers to the term computerized accounting process that is paperless and uses the Internet (Deshmukh, 2006).
}

The focus of this research is to summarize the reviews conducted by accounting application users to explore what aspects they like about the accounting application. Therefore, this research attempts to answer the questions; 1) What is the opinion of accounting application users in using the application?; and 2) What are the features that help accounting application users to prepare financial reports?. The impact of this research is expected to be able to provide literature to SMEs in determining the applications they want to use. Review sentences is obtained from the Play Store and AppStore platforms. Research activities of review summarization have focused on the disciplines of computer technology that are useful in the development of an application. Meanwhile, this study adopts review summarization method in accounting disciplines in the form of observing sentiment analysis of users of accounting applications. This research does not discuss technological aspects but only focuses on aspects of accounting features in helping SMEs prepare financial reports. As a constructivism research, all subjective actions will still be guided by previous theories and research (M. Hu \& Bing, 2004; Indurkhya \& Damerau, 2010).

\section{Literature Reviews}

\section{Accounting Application on Smartphone}

The result of disruption innovation in accounting and technology is a smartphone-based accounting application that functions to run the accounting cycle to produce business financial reports (Desmahary \& Kuswara, 2016). The main point of the accounting application on smartphones is the implementation of the accounting system on smartphone devices. The paradigm shift that occurred is that the accounting system that was previously computer or personal computer based for larger companies and with complex systems now comes with a simpler and free version. If all this time the accounting cycle was adopted with technology on a computer device (Yuliantoro, 2015) now businesses can compile financial reports on a smartphone device. With the accounting application, financial reports and statistics that should be processed on a computer can now be completed with a smartphone (Handayani, 2017). This technological development is able to compile 
financial reports in real time. Not only that, this application also performs cloud computing so that it is able to store databases on a server via the internet (Pramono et al., 2020). This financial report can be relied by SMEs to monitor business performance (Hidayah, Rofiq, Probowulan, \& Aspirandi, 2021; Mahrus et al., 2020).

So far, TAM has constrained the idea that the implementation of information technology in the realm of accounting is caused by two things, namely perceived ease of use and perceived usefulness. Various tests have proven a significant relationship between the perceived ease of use variable and the perceived usefulness variable on the behavioral aspects in using technology (Adi \& Yanti, 2018; Alvin \& Kurniawati, 2019; Budiman \& Arza, 2013; Jalil, 2008; Lucyanda, Fakultas, \& Unisma, 2010). Therefore, with data in the form of review sentences, researchers get the opportunity to elaborate on TAM variables within the scope of constructivism research using unstructured data.

Research in the field of accounting applications on smartphones is still rarely done. Research conducted by (Mahrus et al., 2020) shows that accounting applications on smartphones are difficult to use from the perspective of the technology acceptance model. The research was conducted in the scope of the research object with an interview approach. The accounting application on smartphones used is WiinFeel which was downloaded by 130,000 users. However, minimum research explain the perspective ease of use and perceived usefulness such as (Hetika \& Faidah, 2020; Hidayah et al., 2021; Pramono et al., 2020) in supporting ease of use and perceived usefulness. These studies are conducted minimum scale of objects. Based on the studies, there are research opportunities on a wider data scale, namely the BukuKas application and the Daily Financial Records with a total download of 6.3 million shop owners and SMEs players.

\section{Sentiment Analysis}

Psychological aspects are able to explain why an individual acts both affectively and emotionally (Harrington, 2005). This action is a response to environmental stimuli received by the body's senses. The application of sentiment analysis in the realm of customer opinion has been carried out to explore customer perceptions of a product or service (Khan et al., 2016). Sentiment analysis is part of the Natural Language Program whose job is to extract the meaning of a sentence (Pang \& Lee, 2008). This framework uses social data to conclude an opinion (Tang, Chang, \& Liu, 2019). By using a procedure, this analysis is able to be developed in extracting an opinion. On this basis, sentiment analysis can be carried out to obtain the opinion value of a product or service. In fact, the development of sentiment analysis is also developing in the political realm to assess the opinion of a general election. Therefore, the application of sentiment analysis can be applied to various aspects of opinion assessment.

Sentiment analysis taxonomy distinguishes two approaches in conducting sentiment analysis (Khan et al., 2016). The first approach is sentiment classification which relies on machine learning to analyze a document. However, this approach has a weakness, namely at the document level it has various types of implied and expressed opinions. Therefore, various reviews need to be carried out on the results of the analysis of this approach. The second approach is the unsupervised technique which relies on lexicon analysis to find out the opinion of a sentence. This opinion uses a search engine designed to analyze the adjective opinion of a sentence. This opinion uses statistics to conclude a collection of opinions.

\section{Accounting Terminology}

As a science, accounting has many terms with various meanings. In fact, it is practically possible that different locations for accounting applications arise from different terms. Therefore, one of the objectives of the preparation of international accounting standards is to simplify the business communication process. In fact, the application of accounting standards based on geographic differences creates barriers to the comparability and transparency of financial reports (Taylor \& Jones, 1999). Differences in the use of terms may occur in writing review sentences, therefore a guideline for determining product features related to accounting terms is needed. To study product features related to accounting, this research is directived by (Shim, Siegel, Dauber, \& Qureshi, 2014) provides more than 2,500 accounting terms that are used generally and in standard. With this guideline, product features related to accounting can be determined. Therefore, the discussion of product features in this research is not too broad and only focuses on accounting product features even though technological aspects are still being discussed as the impact of digitizing SMEs financial reports. 


\section{Related Work}

The development of review mining is in line with the activity of application users in reviewing application products. First, it begins with the rating method and then develops into text so that users can easily describe their experience when using the software. Therefore, text-based reviews have begun to assess the sentiment of software users. The credibility of review sentences needs to be considered in order to produce relevant conclusions (Y.-H. Hu et al., 2016). Meanwhile, in our research, credibility has been maintained by the existence of filters for reviews that are inappropriate and spam by Google and Apple platforms.

The research (Maalej, Kurtanovic, Nabil, \& Stanik, 2015) conducted mining reviews on Play Store and AppStore in general. In fact, these studies look at different types of applications and not in the same field. Mining review research with a focus on one type of application will provide more useful information as is done by (Ming et al., 2020) by focusing on COVID-19 health applications. Therefore, our research focuses on one specific type of application, namely an application that functions to compile financial reports. Therefore, the results of this study are able to contribute to SMEs actors in making decisions to choose the suitable application for them.

Studies on the behavior of smartphone-based accounting application users still focus on certain methods. Data collection techniques by approaching
SMEs are a valid method and common (Hetika \& Faidah, 2020; Mahrus et al., 2020; Pramono et al., 2020). However, now there is big data on the opinions of smartphone-based accounting application users that can be studied to gain insight.

\section{Research Method}

The review mining method used in this study implements the Feature-Based Summarization (FBS) by (M. Hu \& Bing, 2004; Widyassari et al., 2020). The FBS method has been implemented by many previous studies (Alhamad \& Kurdy, 2020; Choudhary \& Arora, 2021; Guerrero, Chiclana, Olivas, Romero, \& Homapour, 2020). Figure 1 shows the flow of review mining techniques using FBS.

\section{Part-of-Speech Tagging (POS)}

To digest a sentence so that it can be analyzed, it is necessary to do tagging (M. Hu \& Bing, 2004) by using TagAnt (Anthony, 2015). To be able to process and analyze data, the sentence collection needs to be cut up to the word class. The decapitation in sentences is categorized based on the word structure, namely Noun, Verb, and Adjective. Product features are usually in the form of nouns or noun phrases while opinion words are in the form of adjectives (M. Hu \& Bing, 2004). To be able to do this, a software called TagAnt is used which functions to tag the words inputted (UTF-8 encoded) (Anthony, 2015).

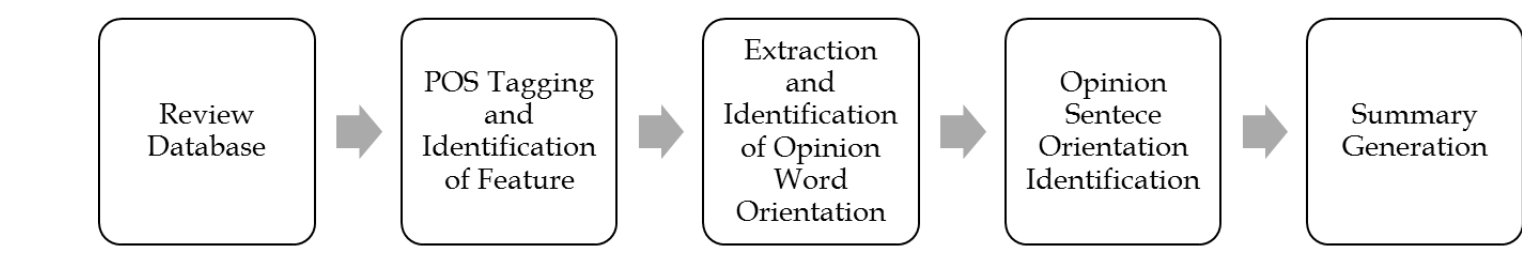

Source: (Hu \& Bing, 2004;168-177 developed by researcher)

Fig. 1 Feature-Based Summarization

The results of data processing using TagAnt are words that have a word structure attribute in the form of XML output, namely $<\mathrm{NN}$ for nouns, NNS for singular nouns, NNPS for proper plural nouns, JJ for adjectives, JJR for comparative adjectives, and JJS for superlative adjectives and so on.

\section{Feature Identification}

At this stage there is a product feature analysis using association mining. A feature will be identified as a noun in a sentence so that the word with the noun 
attribute is searched to determine the product feature (M. Hu \& Bing, 2004). Association mining implements algorithms to determine the presence of accounting application features.

\section{Opinion Words Extraction}

The main task of this stage is to distinguish between opinion sentences and those that are not. Research by (Wiebe, 2000) explains the correlation of adjective subjectivity as the basis for determining opinion words. Therefore, the presence of adjectives is a strong basis for determining opinion. M. Hu \& Bing (2004) suggest to focus on product feature opinion therefore the correlation between adjective and feature word in a sentence will greatly determine opinion words extraction. The method for executing this command can use an algorithm in sentence analysis.

\section{Orientation Identification for Opinion Words}

Opinion words that were successfully extracted from the review database will then be determined the opinion orientation. Research by (M. Hu \& Bing, 2004; Pang \& Lee, 2008) suggests a bipolar analysis of adjectives to determine positive or negative orientation. Positive orientation means good sentiment, while negative orientation means bad sentiment. M. Hu \& Bing (2004) describes the use of WordNet software as a tool to determine the bipolar of an adjective word.

\section{Summary Generation}

The last stage of the FBS is summary generation to conclude the opinions of users of accounting applications. Every sentiment analysis on product features will be concluded based on the results of a positive or negative assessment. If a product feature is dominated by positive ratings, then the product features have a positive sentiment. If a product feature is dominated by negative ratings, then the product features have a negative sentiment. However, if a product feature gets a neutral assessment (the result is the same between positive and negative), it is necessary to analyze the product features that have similar features to get a strong argument for a positive or negative tendency. Therefore, we compiled a tabular table to calculate the dominant value of sentiment polarity for each product feature. With this table, we can draw conclusions about the sentiment trend for each product feature. In addition, we are able to analyze which product features are useful for SMEs in helping them prepare business financial reports.

\section{Result and Discussion}

\section{Database Descriptive}

The population of this research is all accounting software on iOS and AndroidOS, but in order to prioritize the principle of data plurality to represent the population, all applications will be taken and each application will determine the size of the sample reviews to be taken. There are two applications used in this research, namely BukuKas and Catatan Keuangan Harian. The data obtained from the review sentences are big, noisy, incomplete, highly unstructured and linked with social relations. Therefore, compiling and organizing research data will take a long time and be inefficient.

This research data is in the form of qualitative data in the form of review sentences. The data is calculated based on one review sentence. The total review sentences obtained when the researcher downloaded data from the review database in the Playstore and Appstore were 36,341 review sentences. The data is obtained by downloading directly on the Playstore and Appstore websites. The data that has been downloaded is then compiled by the researcher in the same file so that it is ready to be obtained by the FBS. The review protocol on the playstore and appstore has applied an anti-spam review system. This means that the review sentence data in this study is free from spam data. In addition, only application users are allowed to review accounting applications. Therefore, it is certain that the author of the review really has experience using accounting applications.

\section{Word Identification}

The research data in the database is a lot of data. The research data in the database is a collection of review sentences.

\section{Part-of-Speech Tagging (POS)}

All review sentences on both products were processed using TagAnt. The following is the output of the TagAnt process: 


$$
\begin{aligned}
& \text { "So_RB far_RB so_RB good_JJ ._SENT } \\
& \text { Easy_JJ to_TO use_VV and_CC can_MD } \\
& \text { give_VV good_JJ report_NN ._SENT } \\
& \text { Love_VVP to_TO use_VV it_PP._SENT" }
\end{aligned}
$$

In the TagAnt result above, it can be seen that each word has been assigned an attribute based on the word structure. The results will be stored together with the pre-processing data. It can be seen that each word is cut off and given an attribute. For example, the word 'report is assigned the attribute' NN 'which means a noun. Another example is the word 'easy' which is given the attribute ' $\mathrm{JJ}$ ' which means an adjective. This process is carried out for all review sentences that will be used for further extraction activities.

\section{Frequent and Infrequent Features Identification}

The results of the POS analysis will then be followed by association mining analysis. M. Hu \& Bing (2004) explains that an itemset can be accepted as a feature if the appearance value is more than $1 \%$ in the review sentence. In order to determine the significant value (M. Hu \& Bing, 2004) suggests doing a priori algorithm calculation. Table 1 is the results of a priori algorithm-based association mining.

POS analysis not only produces word attributes but also feature suggestions that will be tested for significance using a priori algorithm. The number of feature suggestion tested was 44 words. The test shows that 21 words have a significance value above $1 \%$, while 1 word has no significance value. Words that do not have a significance value will be classified in the infrequent feature. This is because these features are discussed by users of accounting applications, but the number is very small in the population.
Table 1

Frequent and Infrequent Features Identification

\begin{tabular}{lcccc}
\hline \multirow{2}{*}{ Input } & $\begin{array}{c}\text { Feature } \\
\text { Suggestion }\end{array}$ & \multicolumn{2}{c}{ Found features } & \multirow{2}{*}{ Error } \\
\cline { 3 - 4 } & & $\mathbf{> 0 . 0 0 1}$ & $\mathbf{< 0 . 0 0 1}$ & \\
\hline Total & 44 & 8 & 1 & 35 \\
Sentence $=$ & & & & \\
36,341 & & & & \\
Total & & & & \\
Review $=$ & & & & \\
36,341 & & & & \\
\hline
\end{tabular}

The test also produces an error, namely feature words that have no relationship with the features of the accounting application. The number of errors is 22 words.

Opinion Words Extraction

Definition of opinion word (M. Hu \& Bing, 2004) that is, if a sentence contains one or more product features and one or more opinion words. The following is the analysis result of opinion words extraction:

"i_NP love_VVP the_DT simple_JJ way_NN to_TO use_VV this_DT app_NP to_TO write_VV my_PP\$ daily_JJ expense_NN -_SENT"

In the figure above, it can be seen that there is a product feature that appears, namely the word 'expense' which refers to an application feature for recording expenses. In addition, there are opinion words in the form of 'simple'. These two words appear in one review sentence simultaneously. Therefore, it can be concluded from the user's opinion that the application has a simple cost recording feature. 


\section{Orientation Identification for Opinion Words}

The next process is to determine the orientation of a review sentence. It should be noted that only opinion sentences will be analyzed at this stage. The

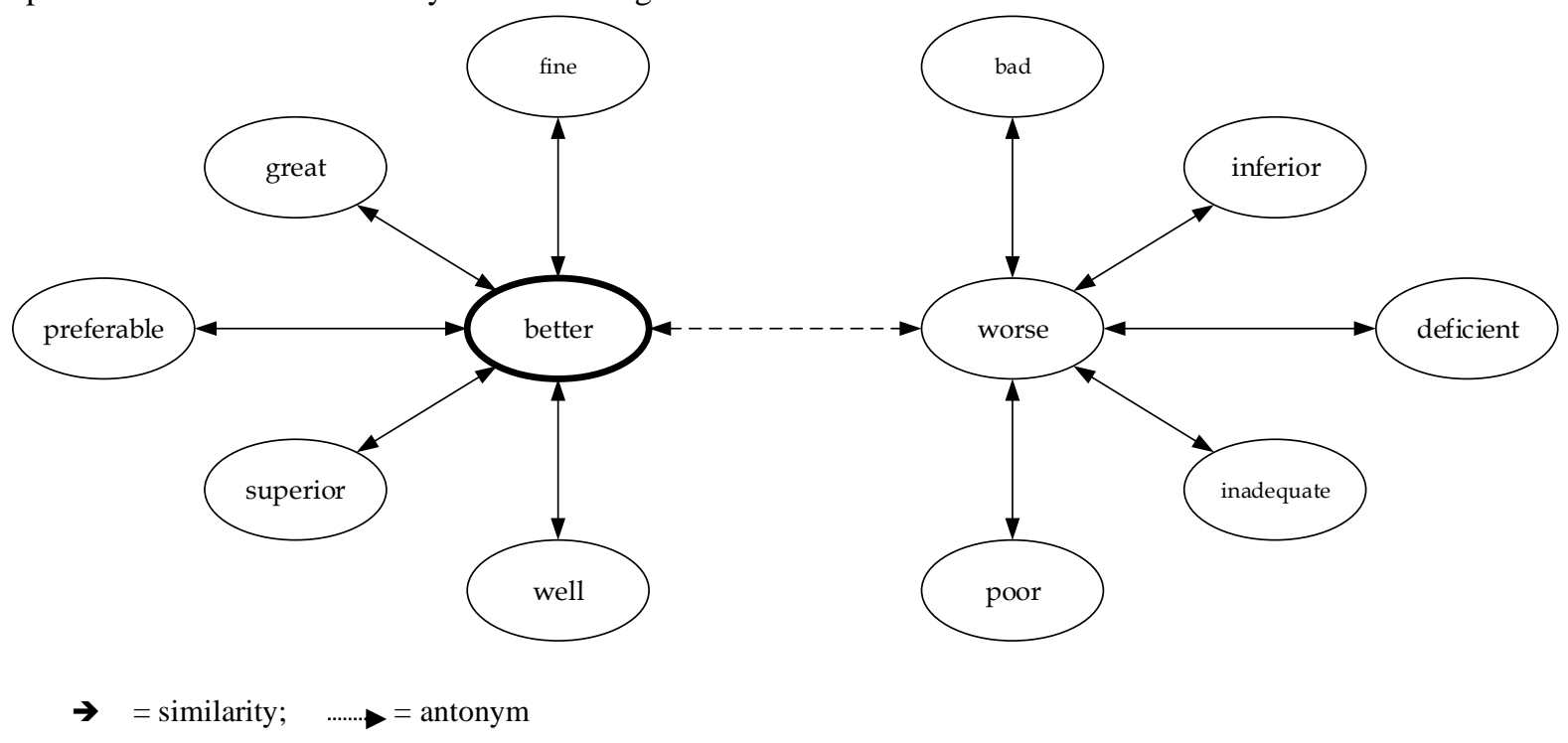

orientation of opinion sentences will be determined to give a value whether a product features are considered positive or negative by users. Researchers used WordNet software to determine the bipolar of a review sentence.

Figure 2. Bipolar Adjective Structure for 'hard'
Figure 2 shows the results of the bipolar analysis of opinion words. Opinion words with positive poles will give positive values on product features. Meanwhile, opinion words with negative poles will give negative value to product features.

\section{Predicting the Orientation of Opinion Sentences}

The determination of the orientation of the opinion sentence is carried out by the dominant analysis of the value of a sentence. M. Hu \& Bing (2004) states that if the orientation value is dominated by positive values, it can be concluded that opinion sentences support product features. If the orientation value is dominated by negative values, it can be concluded that opinion sentences do not support product features. If the orientation value is balanced (between positive and negative the same) then the conclusion will be drawn from the average orientation conclusion. Table 2 is the results of predicting the orientation of opinion sentences.

\section{Summary Generation}

In principle, the product features of the accounting application can be seen in the Play Store and App
Store product descriptions. This study focuses on product features in the realm of accounting to create an analysis of the acceptance of accounting application users. In order to reduce the bias of the definition of accounting terms, this study is guided by a dictionary of accounting terms (Shim et al., 2014). After finding the orientation of the review sentence, the final step is insight analysis. M. Hu \& Bing (2004) suggests arranging product features based on ranking with the number of positive sentiments at the top and the least number of sentiments at the bottom. Following are the results of the preparation of product feature ranking:

Table 3

Rank of Product Features

\begin{tabular}{cll}
\hline Rank & Product Features & Sentiment Value \\
\hline 1 & Report & +2349 \\
2 & Transaction & +302 \\
3 & Bookkeeping & +205 \\
4 & Profit & +92 \\
5 & Category & +85 \\
6 & Customer & +43 \\
\hline
\end{tabular}

The report feature is the application's ability to present business financial reports. Table 4 is sample opinions with positive sentiment. Based on table 4 
above, it can be concluded that the opinions of users of accounting applications are divided into positive and negative opinions even though they are dominated by positive opinions. The report feature is very easy to use in presenting income and expenses with an easy-to-read report presentation. This result is contradictive to the (Mahrus et al., 2020) due to differences on accounting application applied.

Table 4

Sample Opinions for Report

\begin{tabular}{|c|c|c|}
\hline $\begin{array}{l}\text { Opinion Statement } \\
\text { Code }\end{array}$ & Positive Statement & Negative Statement \\
\hline POS001B & $\begin{array}{l}\text { "I use BukuKas because in the application is } \\
\text { easy to use, the report feature really helps } \\
\text { me." }\end{array}$ & \\
\hline POS001B & $\begin{array}{l}\text { "This is really a very useful app, it helps me } \\
\text { on my financial report and tracking all of my } \\
\text { income or expenses." }\end{array}$ & \\
\hline POS002B & $\begin{array}{l}\text { "It is very easy to record daily expenses, the } \\
\text { most important thing is a clear report and easy } \\
\text { to use." }\end{array}$ & $\begin{array}{l}\text { "Simple but very helpful. But the editing part if the } \\
\text { report is misspelled is a little difficult." }\end{array}$ \\
\hline POS002B & & $\begin{array}{l}\text { "Where do you want to show someone the report is } \\
\text { really bad." }\end{array}$ \\
\hline POSO02B & & $\begin{array}{l}\text { "Why is the report tab for the report column per } \\
\text { category when you want to check the information is } \\
\text { always "data is still blank" note. It says info on } 7 \\
\text { October to } 30 \text { at the time it set up manually but still } \\
\text { can't appear \& when the date info doesn't change } \\
\text { even though it always refreshed and restarted." }\end{array}$ \\
\hline
\end{tabular}

BukuKas and Catatan Keuangan Harian provide easy access on financial report compilation. From the result statement, it can be seen that users of accounting applications really like the financial reporting feature. With these financial reports, SMEs can see the company's performance in terms of income and expenses. Financial reports are very helpful for SMEs for reporting business performance for the benefit of the funding prospectus (Andriani, Atmadja, \& Sinarwati, 2014; Harianti, Harahap, \& Hendyansyah, 2020; Hidayah \& Muntiah, 2019). Therefore, by using an accounting application, SMEs can compile financial reports for the purpose of monitoring performance and external funding. This result is coherent to the (Hetika \& Faidah, 2020; Hidayah et al., 2021; Pramono et al., 2020) that accounting application preserve SMEs on financial report. Meanwhile, these product features received negative comments, namely the use of financial statements which had problems with data not being recorded by the system and the editing process of writing which is difficult to use. From the results of these conclusions, there are still errors that occur by the system. Such conditions cause difficulties for SMEs in reading their financial statements.

The transaction feature is the application's ability to record various types of transactions including sales transactions, fees, purchase of supplies. Table 5 is a sample opinion with positive sentiment.

Based on table 5 above, it can be concluded that the opinions of users of accounting applications are divided into positive and negative opinions even though they are dominated by positive opinions. The transaction recording feature makes it easy for SMEs to record sales, purchases and receivables transactions. This result is relevant to the (Hetika \& Faidah, 2020; Hidayah et al., 2021; Pramono et al., 2020) that accounting application giving large access for SMEs in using sales record. With this feature they can record the transaction correctly and safely. SMEs also need a transaction recording system assisted by an information technology system (Achadiyah, 2019). The constraints of SMEs so far will be chaotic transaction recording can be solved (Rayyani, Abdi, Winarsi, \& Warda, 2020; Salmiah, Nanda, \& Adino, 2018) with an automatic transaction recording system. 
Table 5

Sample Opinions for Transaction

\begin{tabular}{|c|c|c|}
\hline $\begin{array}{l}\text { Opinion Statement } \\
\text { Code }\end{array}$ & Positive Statement & Negative Statement \\
\hline POS001A & $\begin{array}{l}\text { "Very helpful sales and purchase } \\
\text { transactions." }\end{array}$ & $\begin{array}{l}\text { "Always must be clicked many repeated to sort the } \\
\text { order of the oldest transaction." }\end{array}$ \\
\hline POS001B & $\begin{array}{l}\text { "Thankyou, although it is simple, bukukas is } \\
\text { quite helpful in recording sales transactions } \\
\text { and accounts payable." }\end{array}$ & \\
\hline POS002B & $\begin{array}{l}\text { "It's cool for online transactions for this } \\
\text { applications, bukukas is an applications that } \\
\text { offers how to transact well and safely, } \\
\text { complete features and usability are perfect for } \\
\text { online market players." }\end{array}$ & $\begin{array}{l}\text { "Very bad in a week the counting system doesn't } \\
\text { load, if you use a password you can't enter again, all } \\
\text { transactions are lost, very disappointing." }\end{array}$ \\
\hline POS002B & & $\begin{array}{l}\text { "The application is simple, but there are several } \\
\text { screens that say it is broken, there is no function to } \\
\text { delete dates that have no transactions in it." }\end{array}$ \\
\hline
\end{tabular}

In addition, this feature is still getting negative sentiments from users. There are several weaknesses of the system in the form of errors that still often appear in the recording.

The bookkeeping feature is the application's ability to record various types of transactions and store transactions and process transactions by category for business financial reporting. The bookkeeping feature does not get negative sentiment from users. Technology aspect is relevant to the (Mahrus et al., 2020) that SMEs need understanding the accounting cycle before use the software. Table 6 is a sample opinion with positive sentiment.

Based on table 6 , it can be concluded that the opinions of users of accounting applications is dominated by positive sentiment. Bookkeeping functions to store all transactions that have been recorded by the system. With this feature, all transactions can be documented. The bookkeeping process is simple and easy to use as consistent to (Hetika \& Faidah, 2020; Hidayah et al., 2021; Pramono et al., 2020) on technical aspect in using application. In addition, there are other features that help users to do bookkeeping. A simple bookkeeping process can help SMEs in preparing financial reports (Hapsari \& Nugroho, 2019; Manoppo \& Pelleng, 2018). This is due to the limitations of SMEs in terms of mastery of accounting knowledge and time constraints.

The profit feature is the application's ability to calculate the net profit earned by the business. Table 7 is a sample opinion with positive sentiment. Based on table 7 above, it can be concluded that the opinions of users of accounting applications are divided into positive and negative opinions even though they are dominated by positive opinions. The profit feature is a feature in the application that is preferred by SMEs. With this feature, SMEs can monitor their profit or loss. Business performance is an aspect that SMEs need to monitor. This result is consistence to (Hetika \& Faidah, 2020; Hidayah et al., 2021; Pramono et al., 2020) that accounting application helps SMEs in generating profit calculation. Various benefits can be obtained from the income statement (Setyawati \& Hermawan, 2018), one of which is the determination of tax calculations (Siswanto \& Sadjiarto, 2014). However, this feature still gets negative opinions from users, namely the difference between manual calculations and calculations on the system. Overall, it can be seen that SMEs actors need the profit feature to know their business performance. In addition, decisions can also be made to improve business performance. 
Table 6

Sample Opinions for Bookkeeping

\begin{tabular}{|c|c|c|}
\hline $\begin{array}{l}\text { Opinion Statement } \\
\text { Code }\end{array}$ & Positive Statement & Negative Statement \\
\hline POS001B & $\begin{array}{l}\text { With complete features, it helps us in the } \\
\text { bookkeeping process. }\end{array}$ & \\
\hline POS001B & $\begin{array}{l}\text { This is a simple bookkeeping application } \\
\text { which can be used for free or for free. }\end{array}$ & \\
\hline POS001B & $\begin{array}{l}\text { The note is super simple, you can make } \\
\text { bookkeeping for } 2 \text { or more outlets but you } \\
\text { can't see the transactions and profits of all the } \\
\text { outlets that we have, only each. }\end{array}$ & \\
\hline
\end{tabular}

Table 7

Sample Opinions for Profit

\begin{tabular}{|c|c|c|}
\hline $\begin{array}{c}\text { Opinion Statement } \\
\text { Code }\end{array}$ & Positive Statement & Negative Statement \\
\hline POS001A & $\begin{array}{l}\text { But the rest is very helpful for calculating } \\
\text { profit and loss etc, the admin is also very } \\
\text { nimble. }\end{array}$ & \\
\hline POS001B & $\begin{array}{l}\text { Free application which is very helpful for } \\
\text { recording and storing financial data, so that } \\
\text { the calculation of profit and flow of funds can } \\
\text { be monitored. }\end{array}$ & $\begin{array}{l}\text { The data is missing a lot, the results are really far } \\
\text { from the manual calculation of profit loss in excel, } \\
\text { wasting my time using this application. }\end{array}$ \\
\hline POS001B & $\begin{array}{l}\text { Very cool monitoring our profits in every } \\
\text { transaction, but I don't understand how to } \\
\text { send a transaction report to WA or email. }\end{array}$ & $\begin{array}{l}\text { Suggestion, for transactions that are not paid, the } \\
\text { profits are not totaled by in those that have been paid } \\
\text { off. }\end{array}$ \\
\hline POS001B & & $\begin{array}{l}\text { My experience, I see there are only menus sales and } \\
\text { expenses, I select the expense menu, the results } \\
\text { increase the expenses so that the profit and loss } \\
\text { report show loss for the purchase of course the report } \\
\text { is like wrong. }\end{array}$ \\
\hline
\end{tabular}

The 'category' feature is the application's ability to differentiate expenditure transaction inputs based on its type (cost of goods sold and operating cost). Table 8 is a sample opinion with positive sentiment. Based on table 8 above, it can be concluded that the opinions of users of accounting applications are divided into positive and negative opinions even though they are dominated by positive opinions. Accounting application users are pleased with the expense transaction taxonomy categorization feature. This result is consistent with Hetika \& Faidah (2020), Hidayah et al. (2021), and Pramono et al. (2020) that the function of accounting application help SMEs in expense transactions. This of course supports the activities of SMEs who have various types of expenses. However, this feature still gets negative opinions, namely errors that still appear after the application is upgraded to the latest version. In addition, the category menu that has been provided cannot be edited based on the terms.

Table 8

Sample Opinions for Category

\begin{tabular}{|c|c|c|}
\hline $\begin{array}{c}\text { Opinion Statement } \\
\text { Code }\end{array}$ & Positive Statement & Negative Statement \\
\hline POS001A & $\begin{array}{l}\text { "Finally, there is an expense report per } \\
\text { category, thank you for the developer." }\end{array}$ & $\begin{array}{l}\text { "When ios update, the existing category menu } \\
\text { recorded in the report will finally duplicate again } \\
\text { when inputting financial data, make me confused." } \\
\text { "Transaction category cannot be edited." }\end{array}$ \\
\hline POS001B & $\begin{array}{l}\text { "More details per category, it's not difficult to } \\
\text { enter the data we want because it's complete." }\end{array}$ & $\begin{array}{l}\text { "For the whole it is good, it's just that I am confused } \\
\text { about how to remove the selection category on } \\
\text { expenses." }\end{array}$ \\
\hline
\end{tabular}


Accounting app users also complain about categories that can't be deleted. Research conducted by (Savitri \& Saifudin, 2018) explains that the accounting process is a very complicated thing. Without sufficient knowledge, SMEs cannot maintain accounting records properly as (Mahrus et al., 2020) that SMEs need proper knowledge on accounting cycle. This perception is generated in the realm of manual accounting, while smartphone-based accounting is done by selecting the desired account category. Therefore, with the product features category, it can help SMEs in recording business transactions.

The 'customer' feature is an application capability in customer transaction management. Table 9 is a sample opinion with positive sentiment. Based on the results of the summarization, there are six product features that are liked by application users, namely; reports, transactions, bookkeeping, profit, category, and customers. Each product feature will be given a positive or negative value in line with the concept of sentiment analysis (Tan \& Zhang, 2007). Users like applications that have a feature in recording transactions based on the categories that have been provided. The result is contrary to the (Mahrus et al., 2020) due to lack of application features. Transactions that have been inputted by the user by the system will be processed to determine the profit generated by the business activity. The profit report is a feature that is liked by users because it is with this feature that SMEs players can easily find out the benefits they get. There are also product features in the form of customers, namely application capabilities in customer management.

Table 9

Sample Opinions for Customer

\begin{tabular}{|c|c|c|}
\hline $\begin{array}{l}\text { Opinion Statement } \\
\text { Code }\end{array}$ & Positive Statement & Negative Statement \\
\hline POS001A & $\begin{array}{l}\text { "Selling home-made coffee milk so you can } \\
\text { see profit and loss and you can find out which } \\
\text { customer has the highest transaction." }\end{array}$ & $\begin{array}{l}\text { "Add the auto paid off feature to the transaction } \\
\text { when the customer has paid it, currently it is still } \\
\text { manual changing the data it seems." }\end{array}$ \\
\hline POS001B & $\begin{array}{l}\text { "Incredible, and application that really helps } \\
\text { small businesses like me, because it saves } \\
\text { time to record cash and collect debts from } \\
\text { customers." }\end{array}$ & $\begin{array}{l}\text { "How come the customer's debt has turned into my } \\
\text { debt?" }\end{array}$ \\
\hline POS001B & $\begin{array}{l}\text { "Nice application display, the best application } \\
\text { for SMEs, very helpful so that sales become } \\
\text { better, easy to track customer accounts } \\
\text { payable, automatic sales reports save time." }\end{array}$ & $\begin{array}{l}\text { "My customer's debt data is lost using the bukukas } \\
\text { app, instead of being safe, it's lost." }\end{array}$ \\
\hline
\end{tabular}

With this feature, SMEs players are able to record every transaction made by their customers. In addition, they can see the performance of customer transactions in differentiating customers with high transactions and low transactions.

This is in line with the TAM concept in the aspect of perceived usefulness (Adi \& Yanti, 2018; Alvin \& Kurniawati, 2019; Budiman \& Arza, 2013; Jalil, 2008; Lucyanda et al., 2010). In addition, from the summarization opinion that users have the opinion of the ease of using the application so that this is in line with the aspect of perceived ease of use in TAM (Adi \& Yanti, 2018; Alvin \& Kurniawati, 2019; Budiman \& Arza, 2013; Jalil, 2008; Lucyanda et al., 2010). Therefore, it can be determined that customers who are loyal to SMEs products or services.

\section{Conclusion}

The purpose of this research is to summarize the reviews conducted by accounting application users to find out what aspects they like about the accounting application. This study contributes practices in terms of behavioral accounting to the use of smartphonebased information technology. The phenomenon raised is that many SMEs players use smartphonebased accounting applications to help them compile business financial reports.

The conclusion of this study is that there are six product features that are preferred by accounting application users. The product features are reports, transactions, bookkeeping, profit, category, and customers. This research has explored product features in accounting applications, but not all product features are discussed by users. Therefore, the discussion on review sentences focuses on the six 
product features. This study is able to provide practical recommendations to SMEs actors in making smartphone-based application decisions they will use. This study recommends SMEs to use accounting applications with the above product features. This is because the strong discussion of opinions on product features explains the preference for product features for SMEs actors in helping them prepare financial reports.

As qualitative research, this study does not have the ability to generalize the results of the study to a population. Our research has been able to compile a smartphone-based accounting application assessment database that comes from unstructured data into data that is neatly organized and can be utilized. Therefore, we suggest for further research to be able to take advantage of the potential of the data we have for the development of testing data on the TAM framework by examining hypotheses.

Based on the results of the study that there are various features that help SMEs in preparing financial reports, it is hoped that SMEs will be able to adopt accounting applications. This is expected to be able to support government programs in the development of the country. SMEs performance transparency is required in tax reporting in accordance with the principles of fairness. The adoption of smartphone-based accounting applications will accelerate the financial transparency of SMEs. This transparency is an achievement in the realm of taxation for the development of the country's economy.

\section{References}

Achadiyah, B. N. (2019). Otomatisasi Pencatatan Akuntansi pada UMKM. Jurnal Akuntansi Multiparadigma.

Adi, I. N. R., \& Yanti, P. E. P. (2018). Pengaruh Computer Attitude, Computer Self Efficiacy, dan Trus Terhadap Minat Menggunakan Software Akuntansi Pada Karyawan LPD Se-Kota Denpasar. Jurnal Ilmiah Akuntansi \& Bisnis, 3(1), 58-70.

Alhamad, E. G., \& Kurdy, M. B. (2020). Feature-Based Sentiment Analysis for Arabic Language. International Journal of Advanced Computer Science and Applications.

Alvin, A., \& Kurniawati, K. (2019). Analisis Penerimaan Audit Software Bagi Auditor Eksternal Dengan Menggunakan Pendekatan Technology Acceptance Model (Tam). Balance Vocation Accounting Journal, 3(2), 1. https://doi.org/10.31000/bvaj.v3i2.2236

Andriani, L., Atmadja, A. T., \& Sinarwati, K. (2014). Analisis Penerapan Pencatatan Keuangan berbasis SAK ETAP pada Usaha Mikro Kecil Menengah (UMKM) (Sebuah Studi Interpretatif pada
Peggy Salon). Jurnal Ilmiah Mahasiswa Akuntansi.

Anthony, L. (2015). TagAnt (Version 1.2.0) [Computer Software] Japan: Waseda University. Available from Http://Www.Laurenceanthony.Net/Software.

Budiman, F., \& Arza, F. I. (2013). Pendekatan Technology Acceptance Model Dalam Kesuksesan Implementasi Sistem Informasi Manajamen Daerah. Wahana Riset Akuntansi, 1(1), 87110. Retrieved from http://ejournal.fip.unp.ac.id/index.php/wra/article/view/2315

Choudhary, A., \& Arora, A. (2021). Linguistic Feature Based Learning Model for Fake News Detection and Classification. Expert Systems with Applications.

Deshmukh, A. (2006). Digital accounting: The effects of the internet and ERP on accounting. IGI Global.

Desmahary, Y., \& Kuswara, H. (2016). Aplikasi Akuntansi Zahir Accounting untuk Pengolahan Data Keuangan pada PD. Anugrah Jakarta. Jurnal Online Insan Akuntan.

Google. (2021). BukuKas - Pembukuan Keuangan UMKM, Aplikasi Kasir.

Grande, E. U., Estébanez, R. P., \& Colomina, C. M. (2011). The impact of Accounting Information Systems (AIS) on performance measures: empirical evidence in Spanish SMEs. The International Journal of Digital Accounting Research.

Guerrero, J. S., Chiclana, F., Olivas, J. A., Romero, F. P., \& Homapour, E. (2020). A T1OWA Fuzzy Linguistic Aggregation Methodology for Searching Feature-Based Opinions. KnowledgeBased Systems.

Guo, X., Zhang, G., Wang, S., \& Chen, Q. (2019). Multi-way matching based fine-grained sentiment analysis for user reviews. Neural Computing and Applications.

Handayani, A. (2017). 5 Aplikasi Android Terbaik untuk Melakukan Akuntansi. Retrieved from Jurnal Apps website: https://jurnalapps.co.id/5-aplikasi-android-terbaik-untukmelakukan-akuntansi-11167

Hapsari, V. D., \& Nugroho, R. (2019). Literasi Akuntansi dan Pemasaran Online Bagi UMKM Desa Tirtonirmolo Kabupaten Bantul. Jurnal Kuat: Keuangan Umum Dan Akuntansi Terapan.

Harianti, A., Harahap, L., \& Hendyansyah, H. (2020). Laporan Keuangan Berbasis Standar Akuntansi Keuangan Entitas Mikro, Kecil, dan Menengah Bagi Pelaku Usaha Mikro. AKURASI: Jurnal Riset Akuntansi Dan Keuangan.

Harrington, A. (2005). Modern Social Theory an Introduction. Oxford University Press.

Hetika, \& Faidah, Y. A. (2020). Aplikasi Akuntansi berbasis Android untuk Menyusun Laporan Keuangan pada UMKM (Studi Kasus pada Usaha Konveksi "Very Convection”). Monex: Journal Research Accounting Politeknik Tegal.

Hidayah, N., \& Muntiah, N. S. (2019). Persepsi Pelaku UKM terhadap Laporan Keuangan Berdasarkan Standar Akuntansi Keuangan Entitas Tanpa Akuntabilitas Publik (SAK ETAP). Jurnal Akuntansi Indonesia.

Hidayah, Rofiq, M., Probowulan, D., \& Aspirandi, R. M. (2021) Pemanfaataan Aplikasi Akuntansi Berbasis Android SI APIK Untuk Menunjang Pelaporan Keuangan UMKM. Jurnal Ilmiah Akuntansi Kesatuan. 
Hu, M., \& Bing, L. (2004). Mining and summarizing customer reviews. KDD-2004 - Proceedings of the Tenth ACM SIGKDD International Conference on Knowledge Discovery and Data Mining, (November), 168-177. https://doi.org/10.1145/1014052.1014073

Hu, Y.-H., Chen, Y.-L., \& Chou, H.-L. (2016). Opinion mining from online hotel reviews - A text summarization approach. Information Processing and Management.

Indurkhya, N., \& Damerau, F. J. (2010). Handbook of Natural Language Processing (2nd ed.). Boca Raton: Taylor and Francis Group.

Jalil, A. (2008). Studi Empiris Tentang Faktor-Faktor Yang Mempengaruhi Kepuasan Pengguna Akhir Atas Aplikasi Sistem Akuntansi Instansi Dan Sistem Akuntansi Aset Tetap Pada Jajaran Kanwil Departemen Agama Provinsi Jawa Tengah.

Jamilah, A. (2020). Pengguna Ponsel di Indonesia Bakal Mencapai 89 Persen Populasi pada 2025. Good News From Indonesia. Retrieved from https:/www.goodnewsfromindonesia.id/2020/10/06/penggunasmartphone-di-indonesia-diperkirakan-mencapai-89-populasipada-2025

Khan, M. T., Durrani, M., Ali, A., Inayat, I., Khalid, S., \& Khan, K. H. (2016). Sentiment Analysis and The Complex Natural Language. Complex Adapt Syst Model.

Lucyanda, J., Fakultas, D. A., \& Unisma, E. (2010). Pengujian Technology Acceptance Model (Tam) Dan Theory Planned Behavior (Tpb). JRAK Agustus, 2(1995), 1-14.

Maalej, W., Kurtanovic, Z., Nabil, H., \& Stanik, C. (2015). On the automatic classification of app reviews. Requirements Engineering.

Mahrus, M. L., Almadia, F., \& Jelita, N. B. (2020). Persepsi Pelaku UMKM terhadap Penggunaan Aplikasi Akuntansi Berbasis Android. Keberlanjutan: Jurnal Manajemen Dan Jurnal Akuntansi, 5(2), 131. https://doi.org/10.32493/keberlanjutan.v5i2.y2020.p131-141

Manoppo, W. S., \& Pelleng, F. A. O. (2018). Pelatihan Penyusunan Laporan Keuangan dengan Teknik Pembukuan Sederhana Bagi Pelaku Usaha UMKM di Kecamatan Malalayang Kota Manado Provinsi Sulawesi Utara. Jurnal Administrasi Bisnis.

Ming, L. C., Untong, N., Aliudin, N. A., Osili, N., Kifli, N., Tan, C. S., ... Goh, H. P. (2020). Mobile Health Apps on COVID-19 Launched in the Early Days of the Pandemic: Content Analysis and Review. JMIR MHealth and UHealth.

Pang, B., \& Lee, L. (2008). Opinion Mining and Sentiment Analysis. Foudnations and Trends in Information Retrieval.
Pramono, I. P., Mardini, R., Suangga, A., \& Ilhamsyah, M. J (2020). Android-Based Accounting Application for MSME. 2nd Social and Humaniora Research Symposium (SoRes 2019). Atlantis Press.

Rayyani, W. O., Abdi, M. N., Winarsi, E., \& Warda, W. (2020). Peningkatan Daya Saing UMKM melalui Optimalisasi Penyusunan Laporan Keuangan. Jurnal Dedikasi Masyarakat.

Salmiah, N., Nanda, S. T., \& Adino, I. (2018). Pemahaman Pelaku UMKM terhadap SAK EMKM: Survey pada UMKM yang terdaftar di Dinas Koperasi dan UKM Kota Pekanbaru. Akuntansi Dewantara.

Savitri, R. V., \& Saifudin. (2018). Pencatatan Akuntansi pada Usaha Mikro Kecil dan Menengah (Studi pada UMKM Mr. Pelangi Semarang). Jurnal Manajemen Bisnis Dan Inovasi.

Setyawati, Y., \& Hermawan, S. (2018). Persepsi Pemilik dan Pengetahuan Akuntansi Pelaku Usaha Mikro Kecil dan Menengah (UMKM) atas Penyusunan Laporan Keuangan. Riset Akuntansi Dan Keuangan Indonesia.

Shim, J. K., Siegel, J. G., Dauber, N., \& Qureshi, A. A. (2014). Dictionary of Accouting Terms. New York: Barron's Educational Series, Inc.

Siswanto, A., \& Sadjiarto, R. A. (2014). Penyusunan Laporan Keuangan dan Penghitungan Pajak Penghasilan pada UMKM Industri Kulit di Surabaya. Tax \& Accounting.

Tan, S., \& Zhang, J. (2007). An Empirical Study of Sentiment Analysis for Chinese Document. Expert Systems with Applications.

Tang, J., Chang, Y., \& Liu, H. (2019). Mining Social media with social theories: a survery.

Taylor, M. E., \& Jones, R. A. (1999). The Use of International Accounting Standards Terminology, A Survey of IAS Compliance Disclosure. The International Journal of Accounting.

Widyassari, A. P., Rustad, S., Shidik, G. F., Noersasongko, E., Syukur, A., Affandy, A., \& Setiadi, D. R. I. M. (2020). Review of Automatic Text Summarization Techniques \& Methods. Journal of King Saud University - Computer and Information Sciences.

Wiebe, J. M. (2000). Learning Subjective Adjectives from Corpora. AAAI.

Yuliantoro, H. R. (2015). Penyusunan Laporan Keuangan Menggunakan MYOB Accounting Versi 18 Pada Toko Sepatu. Jurnal Akuntansi Keuangan Dan Bisnis.

Zhafira, A. N. (2021). BukuKas Raih Suntikan Dana Rp709 Miliar untuk Akselerasi Digital UMKM. Retrieved from Antara News website: https://www.antaranews.com/berita/2161558/bukukasraih-suntikan-dana-rp709-miliar-untuk-akselerasi-digitalumkm\#mobile-src 


\section{Appendix}

Table 2

Review Sentences Orientation

\begin{tabular}{|c|c|c|c|c|c|c|c|c|c|}
\hline \multirow{2}{*}{$\begin{array}{l}\text { Product } \\
\text { Features }\end{array}$} & \multirow{2}{*}{ Positive } & \multirow{2}{*}{ Negative } & \multicolumn{2}{|c|}{ Conclusion } & \multirow{2}{*}{$\begin{array}{l}\text { Product } \\
\text { Features }\end{array}$} & \multirow{2}{*}{ Positive } & \multirow{2}{*}{ Negative } & \multicolumn{2}{|c|}{ Conclusion } \\
\hline & & & Arithmetic & Value & & & & Arithmetic & Value \\
\hline Bookkeeping & 225 & 0 & + & 205 & Multibook & 3 & 0 & + & 3 \\
\hline $\begin{array}{l}\text { Category } \\
\text { Cost of }\end{array}$ & 90 & -5 & + & 85 & Notes & 120 & -12 & + & 108 \\
\hline Goods Sold & 2 & 0 & + & 2 & Payable & 730 & -17 & + & 713 \\
\hline Customer & 47 & -4 & + & 43 & Product & 26 & -4 & + & 22 \\
\hline Earning & 22 & 0 & + & 22 & Profit & 104 & -12 & + & 92 \\
\hline Expense & 676 & -32 & + & 644 & Purchase & 30 & 0 & + & 30 \\
\hline Goods Sold & 2 & 0 & + & 2 & Receivable & 216 & -7 & + & 209 \\
\hline Income & 481 & -33 & + & 488 & Report & 2391 & -42 & + & 2349 \\
\hline Invoice & 27 & -1 & + & 26 & Sales & 1943 & -19 & + & 1924 \\
\hline Loan & 9 & 0 & + & 9 & Supplier & 0 & 0 & Neutral & 0 \\
\hline Loss & 25 & -4 & + & 21 & Transaction & 327 & -25 & + & 302 \\
\hline
\end{tabular}

